\title{
УАK [658.513-049.5+005.934]:005.591.4
}

М. І. Іщенко,

А. е. н., професор, професор кафедри обліку, оподаткування, публічного управління та адміністрування, Криворізький національний університет, м. Кривий Ріг

ORCID ID: 0000-0002-6820-9455

C. В. Капітула,

к. е. н., доцент, Аоцент кафедри фінансів суб'єктів господарювання та інноваційного розвитку, Криворізький національний університет, м. Кривий Ріг

ORCID ID: 0000-0001-9075-2561

Є. В. Міщук,

к. е. н., доцент, доцент кафедри обліку, оподаткування, публічного управління

та адміністрування", Криворізький національний університет, м. Кривий Ріг

ORCID ID: 0000-0003-4145-3711

B. О. Ільченко,

к. е. н., старший викладач економіки, організації та управління підприємствами,

Криворізький національний університет, м. Кривий Ріг

ORCID ID: 0000-0002-1167-3708

DOI: $10.32702 / 2306-6792.2020 .17-18.67$

\section{УАОСКОНАЛЕННЯ СТРУКТУРИ БЕЗПЕКИ ТА МЕТОАИКИ ОЦІНКИ РІВНЯ Й СТАНУ ФІНАНСОВОЇ БЕЗПЕКИ ПІАПРИЕМСТВА В УМОВАХ ТРАНСФОРМАЦІЇ РИНКОВОГО ПРОСТОРУ}

\author{
M. Ishchenko, \\ Doctor of Economic Sciences, Professor, Kryvyi Rih National University, Kryvyi Rih \\ S. Kapitula, \\ $\mathrm{PhD}$ in Economics, Associate Professor, Kryvyi Rih National University, Kryvyi Rih \\ Ie. Mishchuk, \\ $\mathrm{PhD}$ in Economics, Associate Professor, Kryvyi Rih National University, Kryvyi Rih \\ V. Ilchenko, \\ $\mathrm{PhD}$ in Economics, Senior Lecturer, Kryvyi Rih National University, Kryvyi Rih
}

\section{IMPROVING THE SECURITY STRUCTURE AND METHODS OF ASSESSING THE LEVEL AND STATE OF FINANCIAL SECURITY OF THE ENTERPRISE IN THE TRANSFORMATION OF THE MARKET SPACE}

\footnotetext{
Кризові умови господарювання вітчизняних суб'єктів підприємницької діяльності вимагають нових сучасних підходів до розуміння сутності структури безпеки та методики оцінки рівня й стану фінансової безпеки підприємства. Це обумовлено рядом трансформаційних процесів, що відбуваються як у вітчизняній, так і у світовій економіці на теперішній час.

У статті розглянуто проблематику безпеки підприємства, здійснено удосконалення ії структури передусім на основі аналізу змін за останні роки кадрової ситуації в Україні та аналізу відповідних тенденцій, на підставі чого запропоновано удосконалений підхід щодо оцінки фінансової безпеки, який враховує саме зміни на вітчизняному ринку праці та дозволяє більш якісно проводити відповідне оцінювання з наступним управлінням зазначеною економічною категорією.

Також у статті запропоновано методику оцінки стану безпеки фінансово-економічних інтересів підприємства, що враховує відповідні періоди та цикли досягнення таких інтересів, в якості яких може бути обрана залежно віА умов господарювання, періоду життєвого циклу підприємства та задач дослідження довжина будь-якого економічного або виробничого циклу.
} 
Crisis conditions of management of domestic business entities require new modern approaches to understanding the essence of the security structure and methods of assessing the level and state of financial security of the enterprise. This is due to a number of transformational processes taking place in both the domestic and world economy today.

The article considers the issue of enterprise security, improved its structure primarily on the basis of analysis of changes in recent years of the personnel situation in Ukraine and analysis of relevant trends, based on which an improved approach to assessing financial security, which takes into account changes in the domestic labor market and allows to carry out the corresponding estimation with the subsequent management of the given economic category more qualitatively.

The article also proposes a method of assessing the security of financial and economic interests of the enterprise, taking into account the relevant periods and cycles of achieving such interests, which can be selected depending on business conditions, the life cycle of the enterprise and the objectives of any economic or production cycle.

These rates and periods for these indicators can be found in various ways, including using trend equations. As standards for the construction of trend equations, it is proposed to take different values. At the same time, bankruptcy forecasting models, for the most part, have fixed values. For other indicators, it is noted that the threshold values will differ depending on the time of security. Thus, in the current period they may be the best values among companies competitors in the industry of the country of location of the enterprise, in the strategic period - the best values of leading foreign companies in the industry. In cases where it is not advisable to use the best values, they can be replaced by averages (arithmetic, geometric, weighted and others).

The article assesses the state of security of financial and economic interests on the example of Ukrainian mining companies.

To assess the integrated state of security of financial and economic interests, the trend equation is determined by the normative values of indicators of security of financial and economic interests. In determining these regulatory trends, indicators were taken into account only for those enterprises for which the direction of change of indicators corresponds to the direction for most enterprises. The so-called "reverse trend" is used, because it is not essential to assess the security situation: how many quarters back or how many quarters ahead will be reached or another state. More important in this context is the amount of time in which the resources and processes involved in achieving and ensuring a given (desired) level of security are accumulated.

Ключові слова: безпека, структура безпеки, фінансова безпека, фінансово-економічні інтереси підприємства, персонал.

Key words: security, security structure, financial security, financial and economic interests of the enterprise, personnel.

\section{ПОСТАНОВКА ПРОБЛЕМИ}

У сучасних кризових умовах господарювання, що обумовлені синергетичною дією декількох криз - економічною, фінансовою, демографічною, пандемічною тощо, перед багатьма суб'єктами ведення підприємницької діяльності постають нові задачі та завдання. Одними з таких завдань $€$ управління фінансовою безпекою підприємства як одним з головних факторів успішного їх розвитку та ефективної діяльності.

Проблематика фінансової безпеки завжди була актуальною для вітчизняних підприємств, однак зараз вона набуває надактуальності, що пояснюється одночасним збігом ряду несприятливих обставин як для економіки загалом, так і зокрема для практично кожного суб'єкта підприємницької діяльності.

\section{АНАЛІЗ ОСТАННІХ ДОСЛІДЖЕНЬ І ПУБЛІКАЦІЙ}

На сьогодні проблематиці безпеки, економічно та фінансової безпеки як на національ- ному, так і на рівні підприємств присвячено багато праць та розробок. Найвизначними, на нашу думку, є праці Абалкіна А.І., Балики С.Ю., Бланки I.А., Бокова В.В., Вітлінського В.В., Верченко П.І., Аарнопиха Г.Ю., Аовбні С.Б., Козаченко А.В., Аігоненко А.О., Міщенко В.В., Покропивного С.Ф., Паламарчук O.I., Приходько В.В., Терещенко О.О., Шембель Ю.С. та ін.

\section{META CTATTI}

Метою наукової роботи $€$ удосконалення структури безпеки та методики оцінки рівня й стану фінансової безпеки підприємства в умовах трансформації ринкового простору.

\section{ВИКЛАД ОСНОВНОГО МАТЕРІАЛУ}

Повертаючись до теми дослідження, сліА відмітити, що нами було проведено грунтовне дослідження існуючих підходів та теорій щодо визначення термінів "безпека", "економічна безпека" та "фінансова безпека" [1]. 3 метою уникнення повтору вже оприлюднених даних 


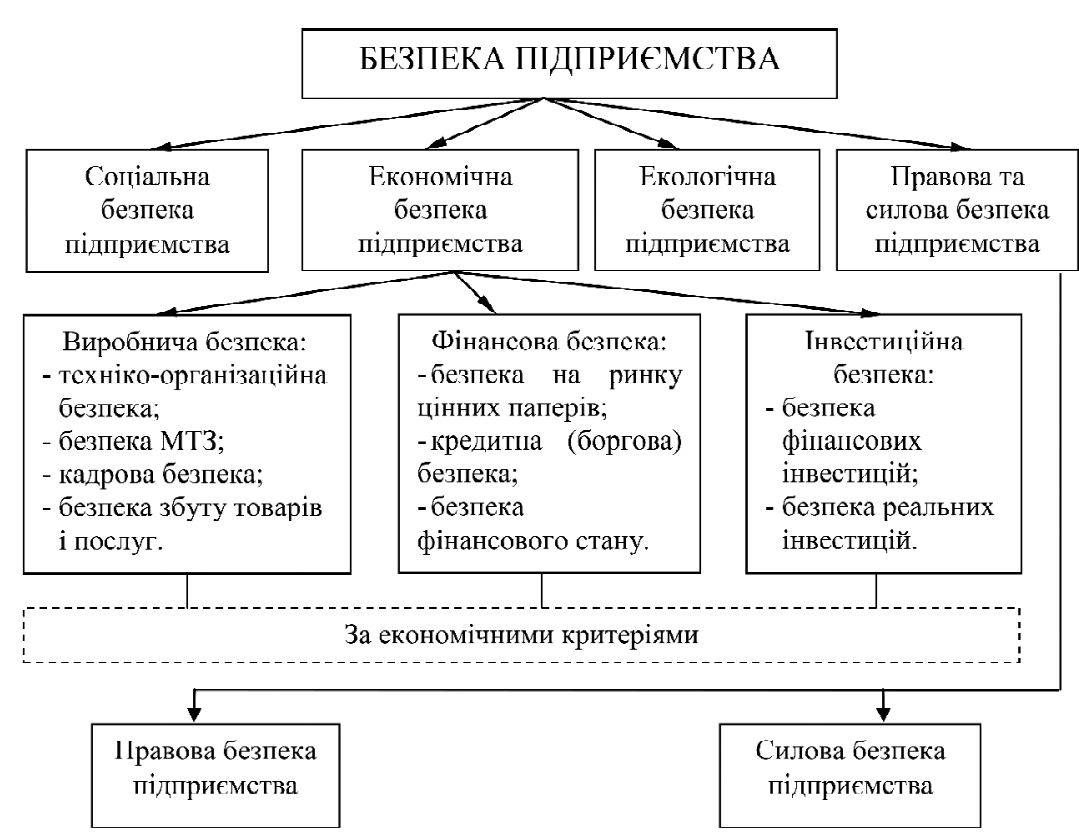

Рис. 1. Первісний вигляд структури безпеки підприємства

Ажерело: [1, с. 16].

наведемо визначення зазначених термінів, що було запропоновано та узгоджено під час попередніх наукових досліджень.

Так, під безпекою на мікрорівні, тобто на рівні підприємства, на нашу думку, варто розуміти "захищеність підприємства від негативного впливу сукупності соціальних, економічних, екологічних, правових та силових внутрішніх і зовнішніх факторів" [1, с. 14]. В той час ми вважали, що безпеку підприємства, а ми розглядали в більшою мірою гірничо-збагачувальні комбінати, як тодішню основу промисловості регіону, слід розділити на чотири складові: економічна, правова та силова безпека, соціальна та екологічна безпека. Соціальну безпеку згідно з існуючими на той момент тенденцій наукової думки ми виділяли окремо, вважаючи що вона або абсолютно не здійснює вплив на фінансову безпеку, або здійснює його мінімально. Наукова та практична робота наступних років довела, що ситуація нині суттєво змінилася і соціальна безпека на сьогодні тісно переплетена 3 кадровою безпекою. Тому вважаємо за доцільне виокремити соціально-кадрову безпеку підприємства.

Під економічною безпекою підприємства нами пропонувалося вважати "захищеність підприємства, а саме: його капіталу, персоналу, матеріальних і нематеріальних активів, прав, позиції на ринках, іміджу і перспектив його подальшого розвитку від негативного впливу сукупності економічних ендогенних і екзогенних факторів" [1, c. 14].

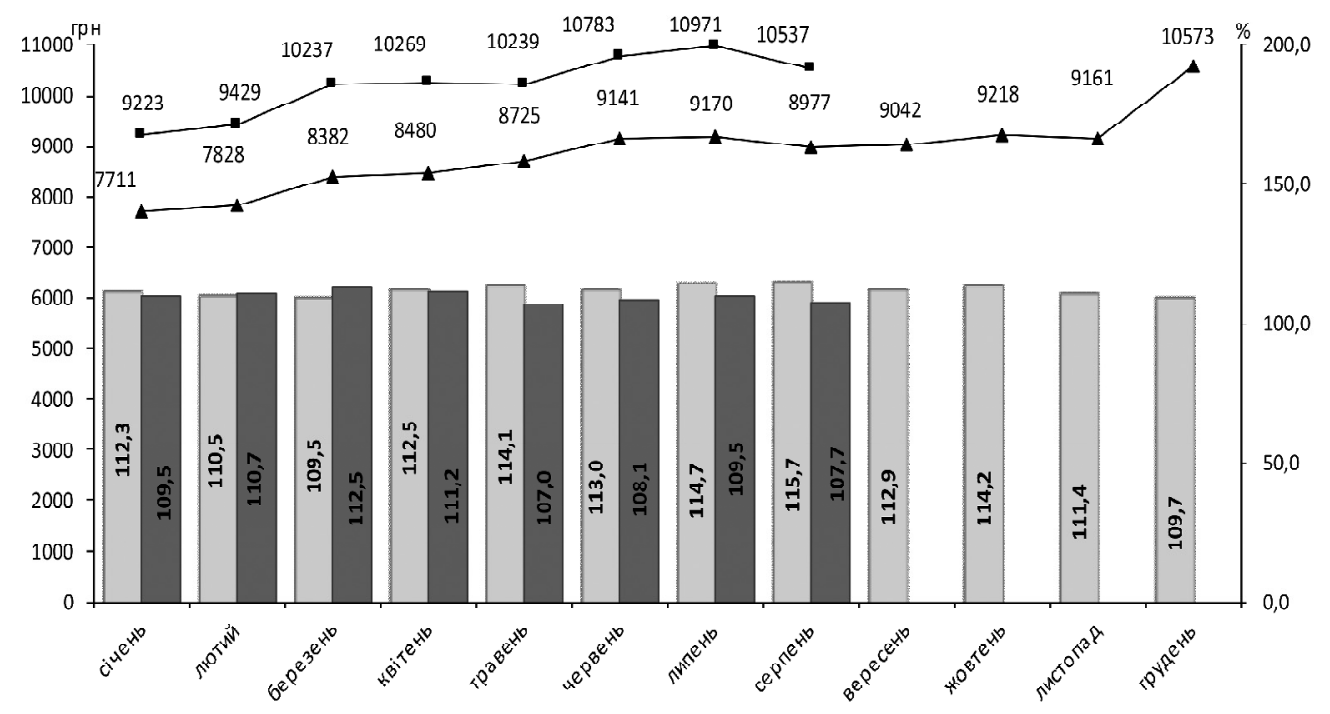

\begin{tabular}{|c|c|}
\hline Z2018 Реальна, \% до відпові дного місяця 2017 року & 2019 Реальна, \% до відповідного місяця 2018 року \\
\hline$\simeq 2018$ ІІомінальна, грн & — 2010 ІІомінальна, грн \\
\hline
\end{tabular}

Рис. 2. Динаміка середньої заробітної плати у 2018-2019 роках

Ажерело: [4]. 


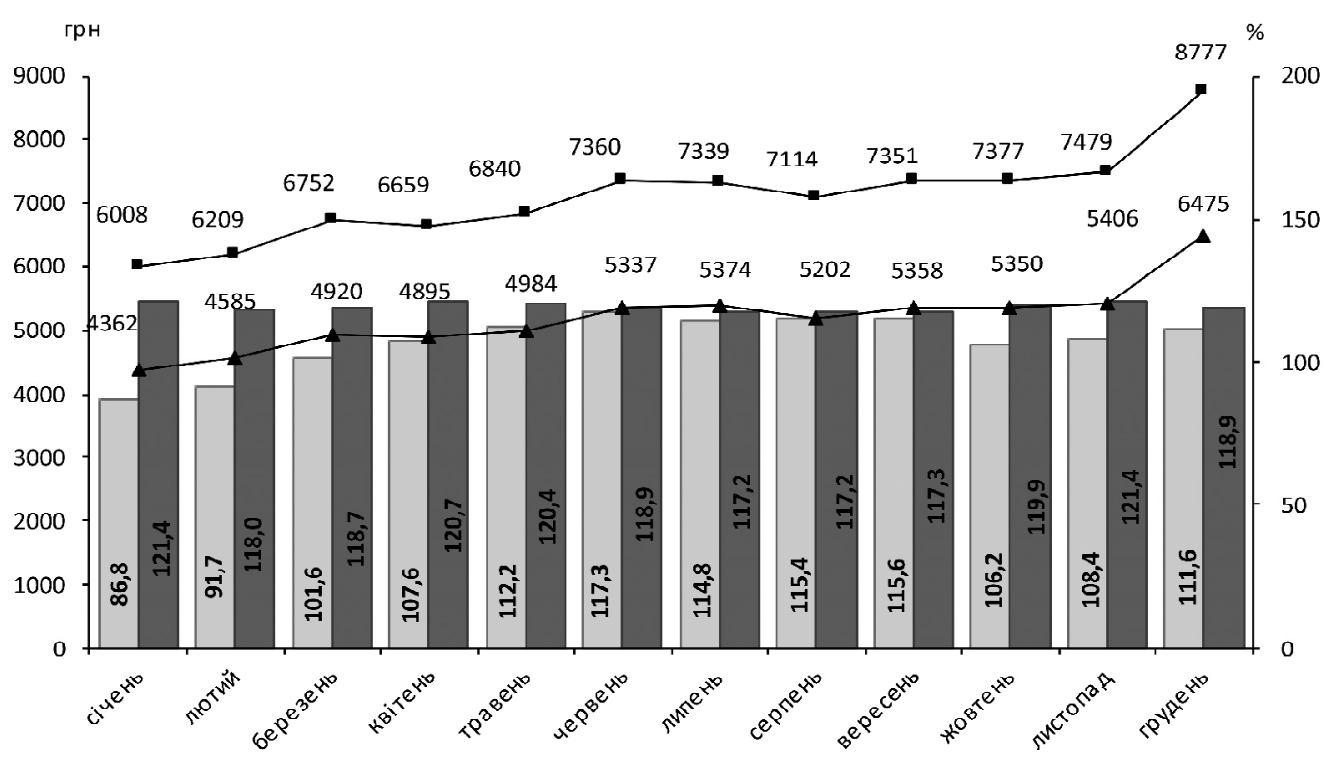

\begin{tabular}{|c|c|}
\hline$\square 2016$ Реальна, \% до відповідного місяця 2015 року & 2017 Реальна, \% до відповідного місяця 2016 року \\
\hline$\longrightarrow 2016$ Номінальна, грн & $\longrightarrow 2017$ Номінальна, грн \\
\hline
\end{tabular}

Рис. 3. Динаміка середньої заробітної плати у 2016-2017 роках

Ажерело: [4].

Структурну схему безпеки підприємств на прикладі гірничо-збагачувальних комбінатів наведено на рисунку 1.

Отже, фінансову безпеку нами пропонувалося розглядати окремо від соціальної та інноваційної безпек підприємства. На той час такий підхід був вірним та оправданим. На сьогоднішній день ситуація дещо змінилася та відповідно слід змінити структуру безпеки підприє- мства, щоб вона відповідала повністю сучасним тенденціям та трендам розвитку економіки.

Одним $з$ таких трендів є фінансове забезпечення кадрового потенціалу вітчизняних підприємств, про що нами була опубліковано відповідну статтю [2].

3 метою отримання повної картини поточної ситуації оновимо статистичні дані, наведені у [2], на рисунках 2-4.

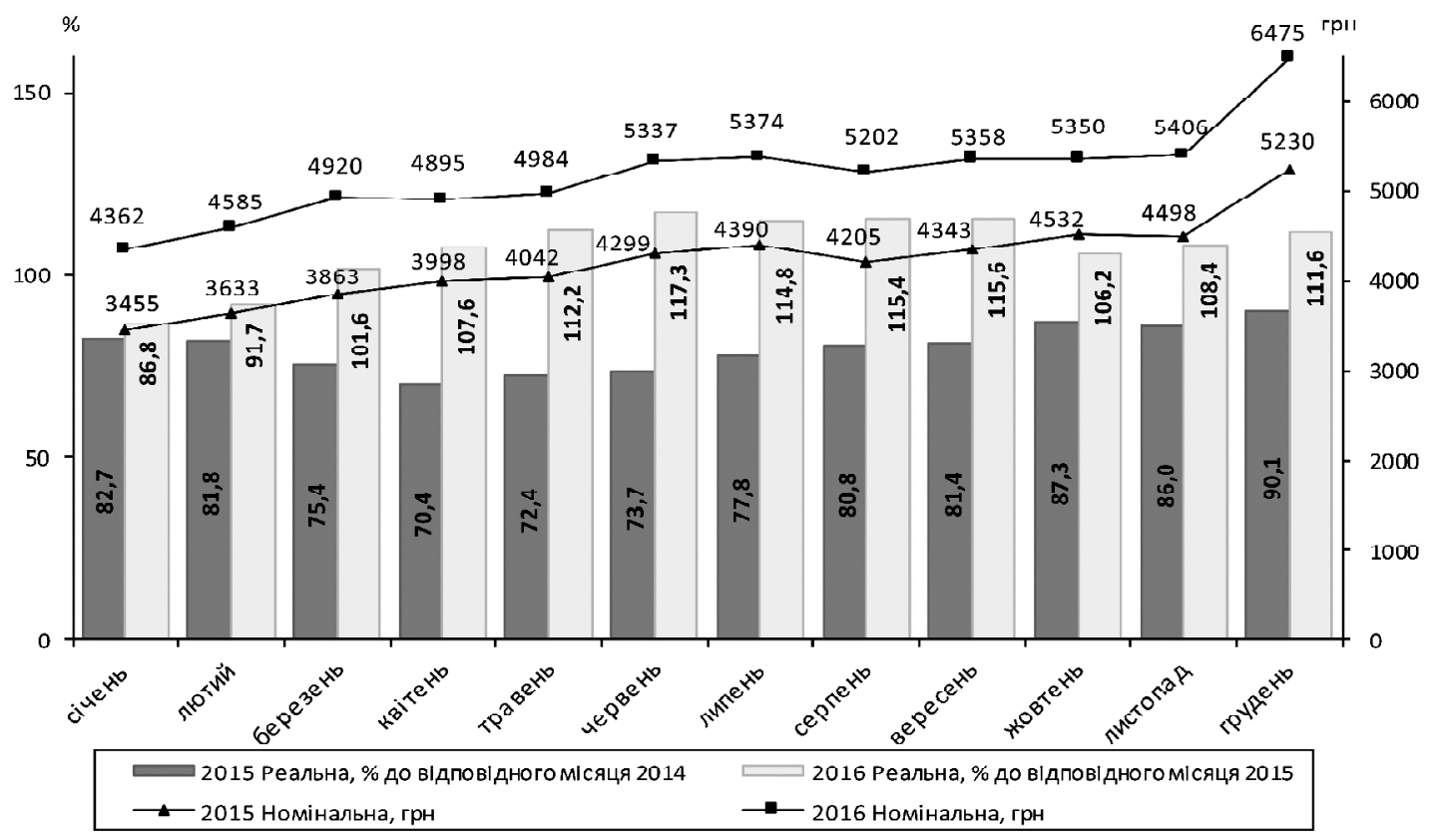

Ажерело: [4].

Рис. 4. Динаміка середньої заробітної плати у 2015-2016 роках 


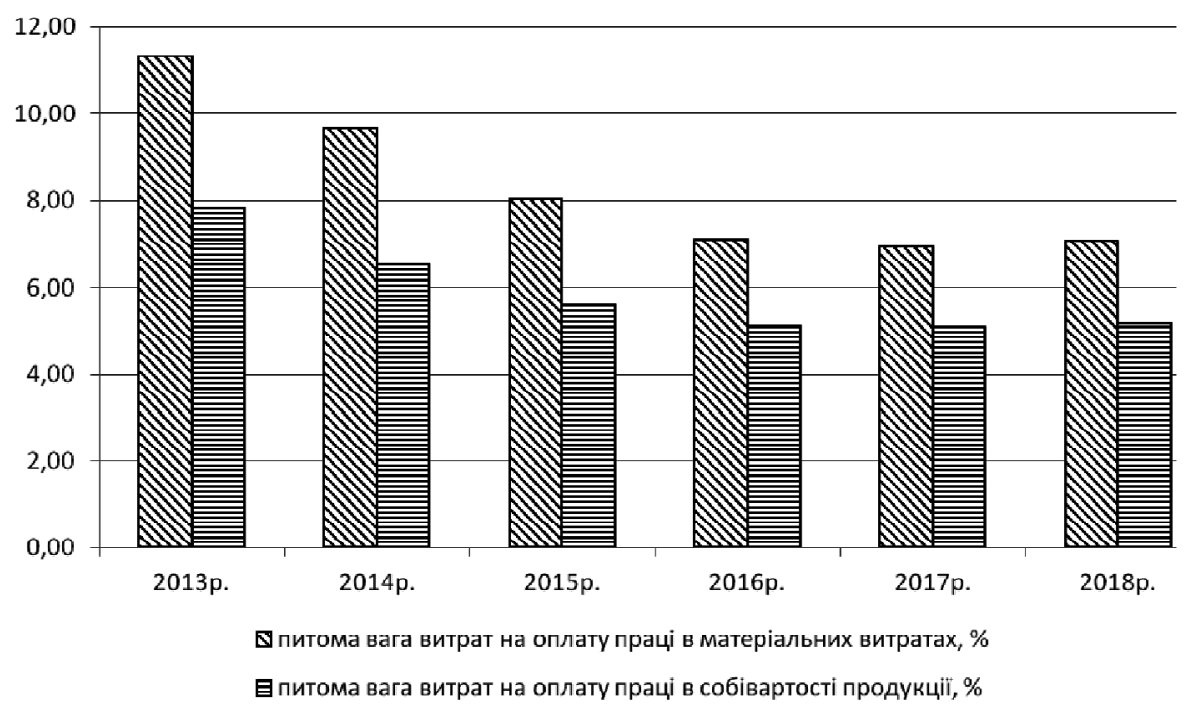

Рис. 5. Динаміка витрат на оплату праці у порівнянні з матеріальними витратами та собівартістю продукції в період 2013-2018 рр. ПАТ "АрселорМіттал Кривий Ріг", \%

Отже, як видно зі статистичних даних, принципово, рівень заробітних плат в Україні має постійну тенденцію до зростання. Це, безумовно, позитивний сигнал, однак у порівнянні із рівнем заробітних плат в Європі, ситуація є негативною. Так, у сусідній Польщі рівень середньої заробітної плати в останній періоддосяг 4271 злотих, що становило станом на початок 2019 року 34400 грн. Тобто порівняння йде явно не в наш бік. Наведені статистичні дані доводять, що ситуація відносно фінансового забезпечення кадрового потенціалу вітчизняних підприємств сигналізує про необхідність негайного втручання та удосконалення.

Як ми вже зазначали, "вихід 3 такої ситуації можливий лише за рахунок підвищення рівня заробітної плати до світового рівня. Однак це не завжди можливо зробити через невідповідність продуктивності праці на вітчизняних та світових підприємствах ГМК. Причин цьому декілька. По-перше, це застаріле обладнання та технології, що потребують заміни та оновлення. ПоАруге, це низький професійний рівень працівників, особливо робітничих професій, що в свою чергу потребує інвестицій у сферу підготовки та перепідготовки кадрів тощо" [2].

Водночас, питома вага фінансових витрат на оплату праці працівників на прикладі
ПАТ "АрселорМіттал Кривий Ріг", як лідера вітчизняної промисловості, має тенденції до змін, які наведено на рисунку 5. Як видно питома вага витрат на оплату праці постійно зменшується, що, безумовно, не впливає позитивно на кадрову безпеку підприємства.

Всі вищенаведені фактори призвели нас до думки, що необхідно удосконалити розроблену нами структуру безпеки підприємства з урахуванням сучасного стану економіки.

У запропонованому удосконаленні ми об'єднали фінансову та інвестиційну безпеку та до підвидів фінансової безпеки віднесли кадрову безпеку в розрізі фінансового забезпечен-

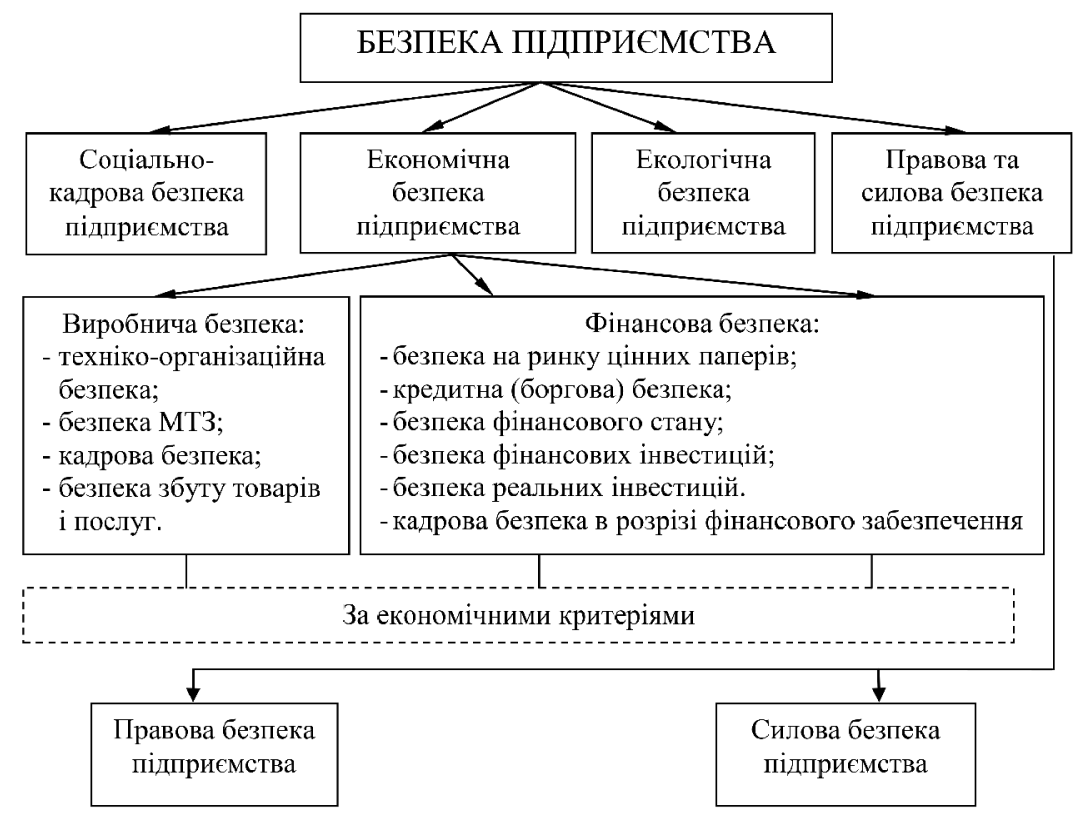

Рис. 6. Удосконалений вигляд структури безпеки підприємства 
ня. Також з урахуванням вищезазначеного ми соціальну безпеку замінили на соціально-кадрову (рис 6).

Таким чином, запропоновані удосконалення дозволять на більш якісному рівні досліджувати проблематику фінансової безпеки підприємства.

Як і будь-яка економічна категорія, фінансова безпека має ряд методів та методик якісної та кількісноӥ оцінки. Ми пропонуємо такий підхід щодо оцінки фінансової безпеки.

$$
R_{\Phi Б}=\prod_{i=1}^{2}\left(1+R_{i}\right)^{\gamma_{i}}=\left(1+R_{1}\right)^{\gamma_{1}}\left(1+R_{2}\right)^{\gamma_{2}}
$$

де $R_{\Phi Б}$ - загальний рівень фінансової безпеки підприємства (інтегральна оцінка);

$R_{1}$ - рівень фінансової складової фінансової безпеки підприємства;

$R_{2}$ - рівень інвестиційної складової фінансової безпеки підприємства;

$\gamma_{i}\left(\sum_{i=1}^{3} \gamma_{i}=1\right)$ - ваговий коефіцієнт відповідного узагальненого показника;

$\gamma_{i}=1-W_{i}, i=\overline{1,2}$ (в якості кількісної оцінки ризику $W_{i}$ доцільно обрати коефіцієнт варіації

$C V(X))$

Оптимальним значенням для показника загального рівня фінансової безпеки підприємства є максимум:

$$
R_{\Phi Б} \rightarrow \max
$$

У зв'язку з тим, що питання кадрового забезпечення фінансової безпеки підприємства $є$ дуже гострим та болючим, слід також його враховувати при оцінці.

Проведені особисті дослідження показали, що взагалі на рівень безпеки підприємства та зокрема на рівень їі фінансової безпеки суттєво впливає старіння персоналу.

Як вже було зауважено в нашій попередній роботі [3] вітчизняні суб'єкти господарювання стикаються з ситуацією суттєвого старіння персоналу на тлі сукупності негативних міграційних, демографічних та економічних процесів. Аля оцінки цього явища по конкретній групі персоналу нами запропоновано використовувати такий показник - коефіцієнт віку персоналу, який ми вважаємо слід розраховувати за наступною формулою:

$$
K_{\text {Bi }}=\frac{B_{\text {РЕAЛi }}}{B_{\text {OПT }}}
$$

де: $B_{\text {PЕААi }}-$ середньозважений вік персоналу, що працює за і-м напрямом (фахом, спеціалізацією тощо). Можна проводити вікову оцін- ку працівників певного підрозділу, департаменту, відділу, філіалу тощо;

$B_{\text {опті }}$ - середній оптимальний вік персоналу, що працює за і-м напрямом (фахом, спеціалізацією тощо). Визначається за допомогою експертних оцінок або методом аналогій.

Розрахунки, проведені нами на основі звітності вітчизняних підприємств, показали, що оптимальне значення цього показника коливається в наступних межах:

$$
0,9<\mathrm{K}_{\mathrm{Bi}}<1,1
$$

Перевищення меж зазначеного показника в той чи інший бік вже є негативним для підприємства, що значно відображається на більшості показників ефективності його діяльності.

Водночас проведені дослідження показали, що проста констатація або визначення середньозваженого віку персоналу є вузьким місцем та дещо обмеженим менеджерським рішенням. На сьогодні практично всі суб'єкти господарювання потребують прогнозування цього показника з метою подальшої оцінки, прогнозування та управління їх кадровою безпекою та й безпекою взагалі.

Відтак вище показано методику оцінки рівня фінансової безпеки підприємства в умовах трансформації ринкового простору. Аля усіх інших умов господарювання, а також для оцінювання стану цього складника економічної безпеки доцільно перейти до його модифікованої структури. У зв'язку із цим пропонуємо розглядати безпеку фінансово-економічних інтересів підприємства, у межах якої диференціювати безпеку достатності прибутку та безпеку фінансової спроможності, зміст яких детально розкрито у роботі [5]. Аля оцінювання стану безпеки фінансово-економічних інтересів (Ci) доцільно скористатися формулою [6]:

$$
C i=1-\frac{\Delta T(Б \Phi E I)}{T u^{\prime}}
$$

де $\Delta \mathrm{T}(Б Ф Е І)$ - період досягнення безпеки фінансово-економічних інтересів підприємства, кварталів;

Тц' - період циклу, кварталів.

У якості циклу, як зазначалося в наших попередніх роботах, може бути обрана довжина будь-якого економічного (або ж виробничого) циклу - усе залежить від умов господарювання, періоду життєвого циклу підприємства та задач дослідження.

Слід указати, що в тому випадку, коли розраховане (прогнозоване) значення періоду досягнення безпеки фінансово-економічних інтересів підприємства (або її окремого складника - 
Таблиця 1. Результати оцінки стану безпеки фінансової спроможності по гірничодобувних підприємствах у 2017-2018 роках

\begin{tabular}{|c|c|c|}
\hline Показник & $31.12 .2017 \mathrm{p}$. & $31.12 .2018 \mathrm{p}$. \\
\hline Порогове річне значення показника Спрінгейта & 0,862 & 0,862 \\
\hline \multicolumn{3}{|l|}{ ПРАТ «ПівнГЗК» } \\
\hline Коефіцієнт рівняння регресії а & 0,5027 & 0,5027 \\
\hline Коефіцієнт швидкості - b & 0,0032 & 0,0032 \\
\hline Квартал, у якому досягається порогове значення & 4 кв. 2017 р. & 4 кв. 2018 p. \\
\hline Період досягнення порогового значення, кварталів & 0 & 0 \\
\hline Показник стану безпеки Сi & 1,00 & 1,00 \\
\hline \multicolumn{3}{|l|}{ ПРАТ «ЦГЗК» } \\
\hline Коефіцієнт рівняння регресії а & 0,3564 & 0,3564 \\
\hline Коефіцієнт швидкості - b & 0,0148 & 0,0148 \\
\hline Квартал, у якому досягається порогове значення & 4 кв. 2017 p. & 4 кв. 2018 р. \\
\hline Період досягнення порогового значення, кварталів & 0 & 0 \\
\hline Показник стану безпеки Сi & 1,00 & 1,00 \\
\hline \multicolumn{3}{|l|}{ ПРАТ «ІнГЗК» } \\
\hline Коефіцієнт рівняння регресії а & 0,2107 & 0,2107 \\
\hline Коефіцієнт швидкості - b & 0,0085 & 0,0085 \\
\hline Квартал, у якому досягається порогове значення & 3 кв. 2016 р. & 3 кв. 2016 р. \\
\hline $\begin{array}{l}\text { Період досягнення порогового значення } \\
\text { (розрахунок за зворотнім трендом), кварталів }\end{array}$ & 5 & 9 \\
\hline Показник стану безпеки Сi & 0,58 & 0,25 \\
\hline \multicolumn{3}{|l|}{ АТ «ПівдГЗК» } \\
\hline Коефіцієнт рівняння регресії а & 0,6432 & 0,6432 \\
\hline Коефіцієнт швидкості - b & 0,0822 & 0,0822 \\
\hline Квартал, у якому досягається порогове значення & 4 кв. 2017 p. & 4 кв. 2018 р. \\
\hline Період досягнення порогового значення, кварталів & 0 & 0 \\
\hline Показник стану безпеки Сi & 1,00 & 1,00 \\
\hline
\end{tabular}

безпеки фінансової спроможності або безпеки достатності прибутку) перевищуватиме значення величини періоду циклу (Тц'), то цей період досягнення приймається рівним періоду циклу.

Своєю чергою період досягнення безпеки фінансово-економічних інтересів підприємства визначається за формулою [6]:

$\Delta T($ БФЕI $)=\frac{\Delta T(\text { БДП }) \times v(\text { (бд) }+\Delta T(\text { БФC) } \times v(\sigma \phi c)}{v(\sigma \partial n)+v(\sigma \phi c)}(6)$

де $\Delta \mathrm{T}($ БДП), $\Delta \mathrm{T}($ БФ) - періоди часу, необхідні для досягнення безпеки достатності прибутку та безпеки фінансової спроможності відповідно, кварталів. Оскільки кожен із указаних складників безпеки характеризується одним індикатором (рентабельністю витрат за операційним прибутком - безпека достатності прибутку та імовірністю банкрутства - безпека фінансової спроможності, то шукані періоди відповідають проміжкам часу, протягом якого відповідні індикатори досягнуть своїх порогових (еталонних, заданих тощо) значень на базовому підприємстві;

v(бдп), v(бфс) 一 швидкості, 3 якими змінюються порогові (еталонні, нормативні, задані тощо) значення відповідно рентабельності витрат за операційним прибутком i Z-рахунку моделі банкрутства, ч.од./час.
Наведені швидкості та періоди щодо перелічених індикаторів можуть бути знайдені різними способами, у т.ч. за допомогою рівнянь трендів. У якості еталонів для побудови рівнянь трендів можуть бути взяті різні величини. Водночас моделі прогнозування банкрутства, здебільшого, мають фіксовані значення (зокрема, для моделі Спрінгейта - це 0,862$)$. Стосовно інших індикаторів (у цьому випадку рентабельності витрат за операційним прибутком) слід відмітити, що порогові (еталонні тощо) значення відрізнятимуться залежно від часової приналежності безпеки. Так, у поточному періоді ними можуть бути найкращі значення серед підприємств - конкурентів у галузі країни місця розташування підприємства, у стратегічному періоді найкращі значення провідних зарубіжних підприємств галузі. У тих випадках, коли не доцільно використовувати найкращі значення, їх можна замінити на середні (арифметичні, геометричні, зважені та інші).

Розглянемо оцінювання стану безпеки фінансово-економічних інтересів на прикладі українських гірничодобувних підприємств.

Слід зазначити, що показник Спрінгейта має лише річне порогове значення, що складає 0,862 . Однак рівняння трендів визначались на підставі квартальних значень. Тому з метою визначення періоду досягнення річного порогового значення було визначено коефіцієнти еластичності для часткових показників, що входять до складу показника Спрінгейта. Аалі на підставі рівняння тренду та коефіцієнтів еластичності визначено прогнозні квартальні значення часткових показників, які було перераховано до річних та визначено річне значення показника Спрінгейту. На останньому етапі отримане річне значення порівнювалось з пороговим значенням.

У таблиці 1 наведено порогові значення індикатора безпеки фінансової спроможності показника Спрінгейта, а також показники стану безпеки фінансової спроможності по гірничодобувних підприємствах.

Як видно з цієї таблиці, на 31.12.2017 р. та 31.12.2018 р. по більшості досліджуваних підприємств такий показник дорівнює 1, тому що на зазначених підприємствах вже досягнуто порогове значення моделі Спрінгейта. Та- 
Таблиця 2. Результати оцінки стану безпеки достатності прибутку по гірничодобувних підприємствах у 2017-2018 роках

\begin{tabular}{|c|c|c|}
\hline Показник & $31.12 .2017 \mathrm{p}$ & $31.12 .2018 \mathrm{p}$ \\
\hline $\begin{array}{l}\text { Порогове квартальне значення рентабельності витрат } \\
\text { за операційним прибутком }\end{array}$ & 1,242 & 0,733 \\
\hline \multicolumn{3}{|l|}{ ПРАТ «ПівнГЗК» } \\
\hline Коефіцієнт рівняння регресії а & 0,5114 & 0,5114 \\
\hline Коефіцієнт швидкості - b & 0,0336 & 0,0336 \\
\hline Квартал, у якому досягається порогове значення & $\begin{array}{l}\text { Понад } \\
12 \text { кварталів }\end{array}$ & 1 кв. 2018 р. \\
\hline $\begin{array}{l}\text { Період досягнення порогового значення Тз } \\
\text { (розрахунок за зворотнім трендом), кварт }\end{array}$ & 14 & 3 \\
\hline $\begin{array}{l}\text { Період досягнення порогового значення Тз } 3 \\
\text { урахуванням циклу, кварт }\end{array}$ & 12 & 3 \\
\hline Показник стану безпеки $\mathrm{Ci}$ & 0 & 0,78 \\
\hline \multicolumn{3}{|l|}{ ПРАТ «ЦГЗК» } \\
\hline Коефіцієнт рівняння регресії а & 0,1763 & 0,1763 \\
\hline Коефіцієнт швидкості - b & 0,0433 & 0,0433 \\
\hline Квартал, у якому досягається порогове значення & $\begin{array}{l}\text { Понад } \\
12 \text { кварталів }\end{array}$ & 3 кв. 2015 р. \\
\hline $\begin{array}{l}\text { Період досягнення порогового значення Тз } \\
\text { (розрахунок за зворотнім трендом), кварт }\end{array}$ & 17 & 9 \\
\hline $\begin{array}{l}\text { Період досягнення порогового значення Тз } 3 \\
\text { урахуванням циклу, кварт }\end{array}$ & 12 & 9 \\
\hline Показник стану безпеки Сi & 0 & 0,26 \\
\hline \multicolumn{3}{|l|}{ ПРАТ «ІнГЗК» } \\
\hline Коефіцієнт рівняння регресії а & 0,264 & 0,264 \\
\hline Коефіцієнт швидкості - b & 0,084 & 0,084 \\
\hline Квартал, у якому досягається порогове значення & 4 кв. 2016 р. & 2 кв. 2018 р. \\
\hline $\begin{array}{l}\text { Період досягнення порогового значення Тз } \\
\text { (розрахунок за зворотнім трендом), кварт }\end{array}$ & 4 & 2 \\
\hline Показник стану безпеки Сi & 0,70 & 0,87 \\
\hline \multicolumn{3}{|l|}{ АТ «ПівдГЗК» } \\
\hline Коефіцієнт рівняння регресії а & 0,5385 & 0,5385 \\
\hline Коефіцієнт швидкості - b & 0,0996 & 0,0996 \\
\hline Квартал, у якому досягається порогове значення & 4 кв. 2017 р. & 4 кв. 2018 р. \\
\hline $\begin{array}{l}\text { Період досягнення порогового значення Тз } \\
\text { (розрахунок за зворотнім трендом), кварт }\end{array}$ & 0 & 0 \\
\hline Показник стану безпеки Сi & 1,00 & 1,00 \\
\hline
\end{tabular}

ким чином, на досліджуваних підприємствах має місце відмінний стан безпеки фінансової спроможності. Виключення складає лише ПРАТ "ІнГЗК". Якщо на 31.12.2017 р. показник безпеки дорівнював 0,58 та мав місце добрий стан безпеки, то на 31.12.2018 р. значення по- казника знизилось до 0,25, що свідчить вже про задовільний стан безпеки.

Зниження показників безпеки спостерігається на усіх досліджуваних підприємствах, окрім АТ "ПівдГЗК". Тому прогнозування виконувалось за "зворотнім трендом" і про від-

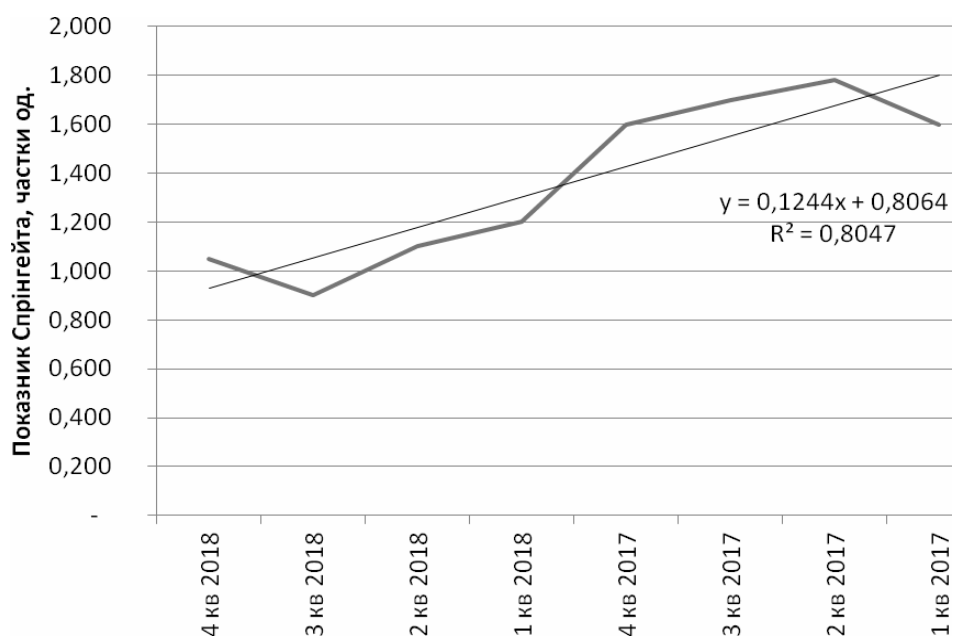

Рис. 7. Нормативний тренд для показника Спрінгейта (в зворотньому напрямку) 


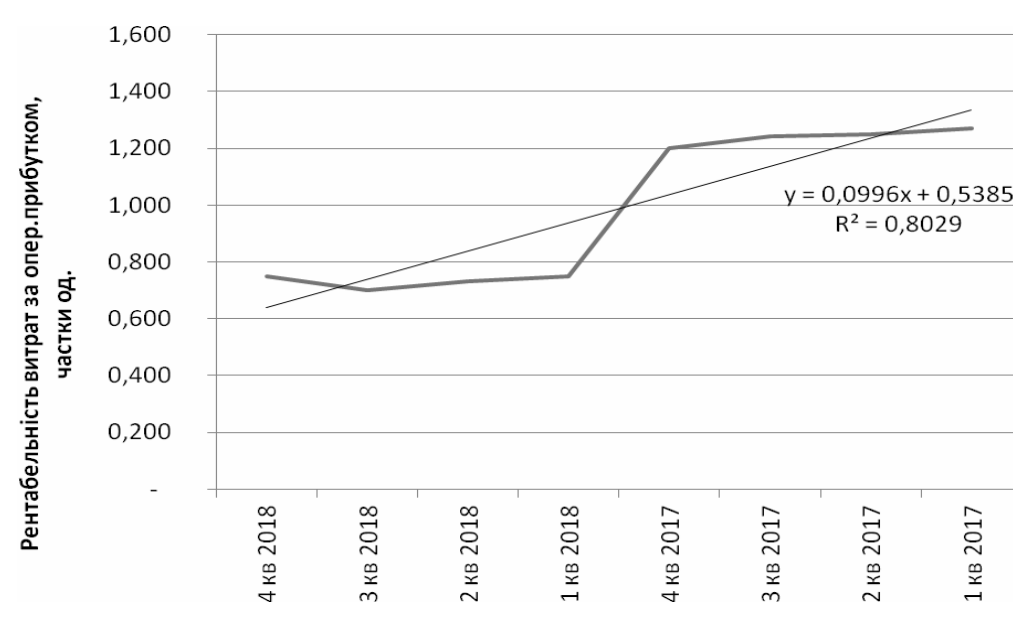

Рис. 8. Нормативний тренд для показника рентабельності витрат за операційним прибутком (у зворотньому напрямку)

мінний стан безпеки на цих підприємствах можна говорити лише у поточній перспективі. Водночас при збереженні тренду зниження у дов-

\section{Таблиця 3. Інтегральні показники стану безпеки фінансово- економічних інтересів по гірничодобувних підприємствах у 2017-2018 роках}

\begin{tabular}{|c|c|c|}
\hline Показник & 31.12.2017 p. & $31.12 .2018 \mathrm{p}$. \\
\hline \multicolumn{3}{|l|}{ ПРАТ «ПівнГЗК» } \\
\hline \multicolumn{3}{|l|}{ Період досягнення порогового значення для: } \\
\hline показника Спрінгейта, кварт & 0 & 0 \\
\hline рентабельності витрат за операційним прибутком, кварт & 12 & 3 \\
\hline $\begin{array}{l}\text { Чисельник інтегрального показника безпеки фінансово- } \\
\text { економічних інтересів }\end{array}$ & 5 & 1 \\
\hline $\begin{array}{l}\text { Інтегральний показник стану безпеки фінансово- } \\
\text { економічних інтересів }\end{array}$ & 0,56 & 0,90 \\
\hline Швидкість зміни інтегрального показника & 0,100 & 0,100 \\
\hline \multicolumn{3}{|l|}{ ПРАТ «ЦГЗК» } \\
\hline \multicolumn{3}{|l|}{ Період досягнення порогового значення для: } \\
\hline показника Спрінгейта, кварт & 0 & 0 \\
\hline рентабельності витрат за операційним прибутком, кварт & 12 & 9 \\
\hline $\begin{array}{l}\text { Чисельник інтегрального показника безпеки фінансово- } \\
\text { економічних інтересів }\end{array}$ & 5 & 4 \\
\hline $\begin{array}{l}\text { Інтегральний показник стану безпеки фінансово- } \\
\text { економічних інтересів }\end{array}$ & 0,56 & 0,67 \\
\hline Швидкість зміни інтегрального показника & 0,100 & 0,100 \\
\hline \multicolumn{3}{|l|}{ ПРАТ «ІнГЗК» } \\
\hline \multicolumn{3}{|l|}{ Період досягнення порогового значення для: } \\
\hline показника Спрінгейта, кварт & 5 & 9 \\
\hline рентабельності витрат за операційним прибутком, кварт & 4 & 2 \\
\hline $\begin{array}{l}\text { Чисельник інтегрального показника безпеки фінансово- } \\
\text { економічних інтересів }\end{array}$ & 4 & 6 \\
\hline $\begin{array}{l}\text { Інтегральний показник стану безпеки фінансово- } \\
\text { економічних інтересів }\end{array}$ & 0,63 & 0,53 \\
\hline Швидкість зміни інтегрального показника & 0,114 & 0,121 \\
\hline \multicolumn{3}{|l|}{ АТ «ПівдГЗК» } \\
\hline \multicolumn{3}{|l|}{ Період досягнення порогового значення для: } \\
\hline показника Спрінгейта, кварт & 0 & 0 \\
\hline рентабельності витрат за операційним прибутком, кварт & 0 & 0 \\
\hline $\begin{array}{l}\text { Чисельник інтегрального показника безпеки фінансово- } \\
\text { економічних інтересів }\end{array}$ & 0 & 0 \\
\hline $\begin{array}{l}\text { Інтегральний показник стану безпеки фінансово- } \\
\text { економічних інтересів }\end{array}$ & 1,00 & 1,00 \\
\hline Швидкість зміни інтегрального показника & 0,112 & 0,112 \\
\hline
\end{tabular}

гостроковій перспективі, на цих підприємствах матиме місце незадовільний стан безпеки.

У таблиці 2 наведено порогові значення індикатора безпеки достатності прибутку.

Як видно 3 цієї таблиці, на 31.12.2017 р. та 31.12.2018 р. по АТ "ПівдГЗК" зазначений показник дорівнює 1, тому що даним підприємством вже досягнуто порогове значення. Таким чином, на АТ "ПівдГЗК" має місце відмінний стан безпеки достатності прибутку. На 31.12.2017 р. на ПРАТ "ПівнГЗК" цей показник дорівнює 0, тому що досягнення порогового значення прогнозується більш ніж через період циклу. Отже, має місце незадовільний стан безпеки. На 31.12.2018 р. по ПРАТ "ПівнГЗК" даний показник суттєво збільшився до 0,78 та вказує на відмінний стан безпеки. На ПРАТ "ІнГЗК" показник стану безпеки також збільшився. Якщо 31.12.2017 р. мав місце добрий стан безпеки, то на 31.12.2018 р. - відмінний стан. На ПРАТ "ЦГЗК" незадовільний стан безпеки як на 31.12.2017 р., так і на 31.12.2018 p. Слід зазначити, що на усіх досліджуваних підприємствах виконувалось прогнозування за "зворотнім трендом" і про відмінний стан безпеки на АТ "ПівдГЗК", ПРАТ "ІнГЗК" та ПРАТ "ПівнГЗК" можна говорити лише у поточній перспективі. Водночас при збереженні тренду зниження у довгостроковій перспективі, на цих підприємствах має місце незадовільний стан безпеки.

Аля оцінки інтегрального стану безпеки фінансово-економічних інтересів визначено рівняння тренду по нормативних значеннях індикаторів безпеки фінансово-економічних інтересів (рис. 7; 8). При визначенні зазначених нормативних трендів враховувались показники лише по тих підприємствах, по яких напрям зміни показників відповідає напрям- 
ку по більшості підприємств. Водночас ми використовуємо так званий "зворотній тренд", оскільки для оцінки стану безпеки не має принципового значення: скільки кварталів назад чи через скільки кварталів наперед буде досягнутий чи інший стан. Більш важливою у цьому контексті видається величина самого проміжку часу, в якому акумулюються ресурси та процеси, задіяні для досягнення й забезпечення заданого (бажаного) рівня безпеки.

Так, по показнику Спрінгейта з вибірки виключено показники АТ "ПівдГЗК", по якому зазначений показник збільшується, на відміну від інших підприємств.

Результати оцінки інтегрального показника стану безпеки фінансово-економічних інтересів наведено у табл. 3.

Інтегральний показник безпеки фінансовоекономічних інтересів по ПРАТ "ПівнГЗК" на 31.12.2018 р. порівняно з 31.12.2017 р. збільшився з 0,56 до 0,90 за рахунок зниження періоду досягнення порогового значення показника рентабельності витрат за операційним прибутком. Загалом на 31.12.2017 р. ПРАТ "ПівнГЗК" добрий стан безпеки, а на 31.12.2018 р. відмінний. Стан безпеки ПРАТ "ЦГЗК", ПРАТ "ІнГЗК" як на 31.12.2017 р., так і на 31.12.2018 p. добрий. По АТ "ПівдГЗК" як на 31.12.2017 р., так і на 31.12.2018 р. відмінний стан безпеки.

\section{ВИСНОВКИ З ПРОВЕДЕНОГО ДОСЛІДЖЕННЯ}

Таким чином, наведені наукові розробки суттєво удосконалюють структуру безпеки та методику оцінки рівня та стану фінансової безпеки підприємства в умовах трансформації ринкового простору, що проявляється в структурних змінах на ринку праці та структури персоналу за її віковим станом тощо.

Впровадження наведених у цій роботі концептуальних засад відповідного в практичну діяльність підприємств дозволить суттєво підвищити їх ефективність господарювання, підвищити рівень та покращити стан фінансової безпеки.

\section{$\Lambda$ ітература:}

1. Капітула С.В. Оцінка та управління економічною безпекою підприємства (на прикладі гірничо-збагачувальних комбінатів України). Аисертація на здобуття наукового ступеня кандидата економічних наук. Кривий Ріг: Криворізький технічний університет. 2009. 207 с.

2. Капітула С.В. Сучасні проблеми фінансового забезпечення кадрового потенціалу підприємств ГМК України. Електронний збірник наукових праць "Сучасні підходи до управ- ління підприємством" Національний технічний університет України "Київський політехнічний інститут ім. Ігоря Сікорського". 2018. С. 160-168.

3. Капітула С.В., Ільченко В.О., Анані Атеф. Авад Фарис. Визначення синергетичного впливу кризових явищ на кадровий розвиток вітчизняних підприємств та інноваційні показники його діагностики. Облік і фінанси. № 4 (82). 2018. C. $131-136$.

4. Аержавна служба статистики України. URL: https:// www.ukrstat.gov.ua

5. Міщук Є.В. Методологія оцінювання рівня безпеки фінансово-економічних інтересів підприємства. Бізнес Інформ. Харків: Видавничий дім "ІНЖЕК", 2020. № 2. С. 245-252.

6. Міщук Є.В. Оцінка стану видів економічної безпеки, розташованих на вищих щаблях її ієрархії (на прикладі безпеки техніко-технологічних інтересів українських гірничодобувних підприємств). Інтернаука. 2020. № 4 (36). Т. 1. C. $36-44$.

\section{References:}

1. Kapitula, S.V. (2009), "Assessment and management of economic security of the enterprise (on the example of mining and processing plants of Ukraine)", Abstract of Ph.D. dissertation, Economy, Kryvoriz'kyj tekhnichnyj universytet, Kryvyj Rih, Ukraine.

2. Kapitula, S.V. (2018), "Modern problems of financial support of personnel potential of MMC enterprises of Ukraine", Elektronnyj zbirnyk naukovykh prats' "Suchasni pidkhody do upravlinnia pidpryiemstvom" Natsional'nyj tekhnichnyj universytet Ukrainy "Kyivs'kyj politekhnichnyj instytut im. Ihoria Sikors'koho", pp. 160-168.

3. Kapitula, S.V. Il'chenko, V.O. and Farys, A.A.A. (2018), "Determining the synergistic impact of crisis phenomena on the personnel development of domestic enterprises and innovative indicators of its diagnosis", Oblik i finansy, vol. 4 (82), pp. $131-136$.

4. State Statistics Service of Ukraine (2020), available at: http://www.ukrstat.gov.ua/ (Accessed 10 Sept 2020).

5. Mischuk, Ye.V. (2020), "Methodology for assessing the level of security of financial and economic interests of the enterprise", Biznes Inform, vol. 2. S. 245-252.

6. Mischuk, Ye.V. (2020), "Assessment of the state of economic security, located at the highest levels of its hierarchy (on the example of security of technical and technological interests of Ukrainian mining companies)", Internauka, vol. 4 (36), no. 1 , pp. 36-44.

Стаття надійшла до редакиї 15.09.2020 p. 